\title{
An Empirical Study of Stressors among Multimedia University Students: A Case of MMU Malacca Campus
}

\author{
Nor Fauziana Ibrahim ${ }^{1}$ and Abdul Manaf Bohari ${ }^{2}$ \\ ${ }^{1}$ Multimedia University, Melaka, Malaysia \\ ${ }^{2}$ UUM College of Business, Sintok, Kedah, Malaysia
}

\begin{abstract}
Stress has become an important issue in university environment as well as in the real society. Many scholars in the field of behavioral science have carried out extensive research on stress and its outcomes and concluded that the issues of stressor are needed more attention. Specifically, stress in academic institutions can stimulate both positive and negative consequences that were depending on some factor. The main objective of the study is to identify the highest types of stress among students. Secondly, the study will explore the relationship between identified stressors and successful factor of student. This study used the survey method where 216 respondents has respons to the questionnaires. The study was applied to diploma students of Multimedia University Malacca Campus. One of finding shows that 89.7 percents students experienced stress, and 10.3 percent student's not experiencing stress. Using logistic regression test, the findings of the study indicates that there are many other factors influences students stress such teaching quality/relations with lecturers, financial and environmental (campus and administrative) of the students which is can give impact in students life. Investigating the different areas where stress occurs can help students learn ways to cope with their stress.
\end{abstract}

Keywords: Stress; Students; University.

\section{Introduction}

Recently, stress has become an important topic in university circle as well as in our society. Many scholars of behavioral science disciplines have carried out extensive research on stress and concluded that the topics are needed more attention from time to time as in (Rees and Redfern, 2000), (Ellison, 2004) and (Ongori et al.,2009). Stress in academic institutions can have both positive and negative consequences if not well managed where it cited in (Smith, 2002), (Tweed et al., 2004) and (Stevenson and Harper, 2006). In addition, the adaptation to
University life can bring a huge amount of stress that the students to encounter. Living away from home, meeting new friends, challenging school work assignments, finding a job, and adjusting to residence hall life can make a student feel overwhelmed as discussed in (Ratanasiripong et al., 2005). According to (Bessie Ong \& K C Cheong, 2009) many discover themselves encountering stress and anxiety about a variety of new challenges. Their personal coping techniques may affect how they handle these stressors. Students suddenly experienced 'newfound' freedom never enjoyed before such as the lack of rigid

Copyright (C) 2012 Nor Fauziana Ibrahim and Abdul Manaf Bohari. This is an open access article distributed under the Creative Commons Attribution License unported 3.0, which permits unrestricted use, distribution, and reproduction in any medium, provided that original work is properly cited. Contact author: Nor Fauziana Ibrahim E-mail: fauziana.ibrahim@mmu.edu.my 
school regulations and the absence of dress codes which can be stressful. This is because now they have to make a lot of decisions on their own.

With regard to (Rees and Redfern, 2000), (Ellison, 2004), (Smith, 2002) and (Bessie Ong \& K C Cheong, 2009), as students' progress through their university livelihood, they may discover the unique responsibilities of adult life becoming increasingly difficult. Challenging stimulus can lead to positive outcomes such as motivation and improved task performance while distress can result in anxiety, feelings of loneliness, nervousness depression, social dysfunction, sleeplessness and even suicidal intention. This is similar to (Ongori et al., 2009), (Tweed et al., 2004) and (Stevenson and Harper, 2006). In addition, it is important that stress management programs be created to address stress among university students. However, in order to create an effective stress management program, the stressor specific to university students must be identified.

\section{Motivation of the Study}

Recently, a study by (Richlin-Klonsky et al., 2003) found that stress is a physical and mental response to everyday demands, particularly those associated with change. It is normal for students to experience stress, especially as they adjust to college life at a highly competitive institution. However, if stress is severe and/or prolonged, it can reduce academic performance; interfere with a student's ability to participate in and contribute to campus life; and increase the likelihood of substance abuse and other potentially damaging behaviors. In Malaysia, researchers as (Redhwan et al., 2009) mention a handful of studies conducted on stress and coping styles focused on nurses, international students, school athletes, university students, and medical students and among prescience students. With regard to (Richlin-Klonsky et al., 2003) and (Redhwan et al., 2009) as well as (Stevenson and Harper, 2006), (Ratanasiripong et al., 2005) and (Bessie Ong \& K C Cheong, 2009), however not much studies have been conducted to understand the identified stressors (Academic, Time/Balance, Interpersonal/Self, Relationship/Social and Family) among university students, Malaysian Universities includes Multimedia University of Malaysia (MMU). Therefore, it would be great to identify which stressors cause the highest types of stress among them.

\section{Objective of the Study}

The objectives of the study are to:

- Identify the highest types of stress among students in the MMU at the MMU Malacca Campus.

- Exploring the relationship between identified stressors with the successful factors.

\section{Selected Literature Review}

Students in their teens are the ones who are going through the transitional phase, which is an intermediate of childhood and adulthood. During the teen years, a lot of biological, physical, mental and emotional changes are happening, as well as the changes in responsibility and role, as in (Tajularipin et al., 2009). In order to stabilize these changes, the students are always confronted with problems and conflicts, as in (Asri, 2002). For some not capable of dealing with it, scholar as (Newman, 2005) coined the changes will create stress and tension to them. If it is not dealt with in the early stages, the student may experience mental problems. In addition, a student's life is subjected to different kinds of stressors, such as the pressure of academics with an obligation of success, uncertain future and difficulties envisaged for integration into the system as mention by (Babar T.S et al., 2004). These students face social, emotional and physical and family problems which may affect their learning ability and academic performance as discuses in (Fish and Nies, 1996) and (Chew- Graham et al., 2003) as well as mention before in (Ellison, 2004), 
(Tweed et al., 2004) and (Richlin-Klonsky et al., 2003).

Recently, the young student population has always been vulnerable to stressful life conditions especially in pursuit of higher professional education in a highly competitive environment according to (World Health Organization, 1994) and (Saipanis, 2003). According to (Brittany Gower et al., 2007) attending a university or college for the first time can be a stressful experience for many new college students. The experience of stress is likely to be a regular occurrence in the lives of new college students, given the nature of the transition that they are making. Currently, a study by (Campbell, 2006) defines stress as the adverse reaction people have to excessive pressure or other types of demands placed on them. Stress occurs when an individual is confronted by a situation that they perceive as overwhelming and cannot cope up with. In addition, (Greenberg and Baron, 2000) define stress as a complex pattern of emotional states, physiological reactions and related thoughts in response to external demands". They refer to the demands emanating from the environment as stressors. Examples of stressors are: the demands of work assignments, interpersonal relations between co-workers, one's relations with one's spouse and children, and social obligations. The third term, strain connected to stress and stressors, according to these authors, refers to the accumulated effects of stress expressed as deviations from normal patterns of behavior or activity and thus constituting a consequence to the exposure to stressful events.

Stressors described such definitions included the following: anything that may cause you to worry or it's a feeling of having too much to do with not a lot of time to do it for me, anything that may cause someone to get upset or frustrated and things that cause us to worry or become almost irritable as cited in (Maureen, 2009). Meanwhile, children are most affected by ongoing, enduring experiences, in particular those over which they have no control. Daily hassles form the main cause of stress experiences in children as cited in (Jewett, 1997), (McNamara, 2000) and (Lohaus, 1990). For example, in an interview study by (Lohaus, 1990) with 342 children and adolescents aged 7 to 16 years, 246 children (72\%) reported stressful situations related to school and performanceoriented contexts (e.g. written class exercises or homework), and 123 (36\%) also reported situations related to social problems (as quarrels with peers or with parents).

Specifically, academic stress among students have long been researched on, and researchers have identified stressors include too many assignments, competition with other students, failures, lack of pocket money as mention by (Fairbrother and Warn, 2003). In addition, others factors are poor relationships with other students or lecturers, family or problems at home. Institutional (university) level stressors are overcrowded lecture halls, semester system, and inadequate resources to perform academic work, as mention in (Ongori, 2007) and (Awino and Agolla, 2008). This is similar to (Campbell, 2006), (Jewett, 1997) and (World Health Organization, 1994) as mention early.

Academic performance was also found to be impaired for students who reported high levels of stress as in (Lumley and Provenzano, 2003) and (Struthers et al., 2000). Physical, psychological, behavioral, and academic difficulties were the cause of stress for college students. Types of schoolrelated stressors include academic performance, attendance, interactions with teachers, and balancing one's leisure time with school also mention in (Brittany Gower et al., 2007). Earlier inventories of schoolrelated stressors indicated nine types, including inadequate instructional methods, teacher-student relationships, heavy academic workload, poor physical classroom environments, and disorganization surrounding, academic assignments and schedules as well as discussed by (Burnett et al., 1997). 
In addition, research has consistently shown high levels of stress experienced by university students as in (Swick, 1987) and (Felsten and Wilcox, 1992). For example, a study by (Abouserie, 1994) investigated stress in undergraduates in relation to locus of control and self-esteem and found that they were experiencing a whole host of academic and life stressors. Studying for examinations and worrying about results were deemed to be the most problematic, followed by having too much to do and the amount to learn. Of course, these are in tandem with other life stressors that they encounter as mention in (Travers, 2010) as well as proven conceptually and practically in (Greenberg and Baron, 2000), (Maureen, 2009), (Ongori, 2007), (Lohaus, 1990) and (Swick, 1987).

\section{Methodology of the Study}

This study used the survey method where diploma students of Multimedia University Malacca Campus were selected as respondents. The study was applied to the students, specifically in various programmes of Diploma, as well as Diploma in Information Technology, Diploma in Accounting, Diploma in Business Administration, Diploma in Electronics
Engineering, Diploma in Telecommunication Engineering, and Diploma in Business Information Systems. The questionnaires were adopted from (Burge's, 2009) with using 5 point Likert scale type. Totally, 250 questionnaires were distributing to 250 students and a total of 216 respondents responded to the questionnaires. In addition, logistic regression allows testing models to predict categorical outcomes with two or more categories.

\section{Findings of the Study}

\section{A. Descriptive Analysis}

Student's demographics, background information and response rate are shown in Table 1 and above graphical display. A total of 216 respondents participated and completed the questionnaire. For age distribution, $86.6 \%$ (187 out of 216) were age between $17-20$ years, $12 \%$ (26 out of 216) were age between $21-24$ years, $0.9 \%$ (2 out of 216) were age between 25-28 years and $0.5 \%$ ( 1 over 216 ) were age range elder than 29 years. From the total, 121 (56\%) respondents are male and 95 (44\%) respondents are female.

Table 1. Demographic Profail

\begin{tabular}{|llll|}
\hline Classification & Ranges & Frequency & Percentage (\%) \\
\hline Age & $17-20$ & 187 & 86.6 \\
& $21-24$ & 26 & 12.0 \\
& $25-28$ & 2 & 0.9 \\
Gender & $>29$ & 1 & 0.5 \\
Relationship Status & Male & 121 & 56.0 \\
& Female & 95 & 44.0 \\
& Single & 161 & 74.5 \\
& In relationship & 44 & 20.4 \\
Nationality & It's complicated & 6 & 2.8 \\
& Married & 4 & 1.9 \\
Religion & Missing & 1 & 0.5 \\
& Malaysian & 210 & 97.2 \\
& International & 5 & 2.3 \\
& Missing & 1 & 0.5 \\
& Muslim & 75 & 34.7 \\
& Buddhist & 114 & 52.8 \\
Period of study in MMU (years) & Hindu & $\mathbf{1 4}$ & 6.5 \\
& Christian & 11 & 5.1 \\
& Other & 2 & 0.9 \\
& -1 & 40 & 18.5 \\
& $1-3$ & 169 & 78.2 \\
& 4-6 & 6 & 2.8 \\
& $7-10$ & 1 & 0.5 \\
& Total & 216 & 100 \\
\hline
\end{tabular}


Based on Table 1, 74.5\% with 161 respondents are single status, $20.4 \%$ with 44 respondents are in relationship status, $2.8 \%$ with 6 respondents are in complicated relationship status and $0.5 \%$ with 4 respondents is married. Based on the religions category, it can be seen that 114 out of $216(52.8 \%)$ are Buddhist students. 75 out of 216 (34.7) are Muslim students, 14 out of 216 students $(6.5 \%)$ are Hindu students, 11 out of 216 students (5.1\%) are Christian students and finally, 2 out of total respondents with $0.9 \%$ are falls in others in religion question.

For the period study in MMU, values given in the descriptive results are $78.2 \%$ with 169 respondent's falls in the range of 1 to 3 years. $18.5 \%$ with 40 respondents falls in the range of less than 1 year. $2.8 \%$ with 6 participants agreed that their period of study is between 4 to 6 years. 1 out of total students $(0.5 \%)$ responded that the period of his/her study takes between 7 to 10 years.

\section{B. Logistic Regression (Testing Assumption)}

Table 2 shows the part of the output that test assumption. Study interested only in whether the interaction terms are significant. Any interaction that is significant indicates that the main affect has violated the assumption of linearity of the logit. All five interactions have significance values greater than 0.05 , Academic (0.998), Time/Balance (0.583), Intrapersonal/Self (0.066), Family (0.127) and Relationship/social (0.331). The results indicating that the assumption of linearity has met for Academic, Time/Balance Intrapersonal/Self, Family and Relationship/social.

Table 2. Linearity of the Logit

Variables in the Equation

\begin{tabular}{|c|c|c|c|c|c|c|c|}
\hline & & B & S.E & Wald & df & Sig. & $\operatorname{Exp}(B)$ \\
\hline \multirow{11}{*}{$\begin{array}{l}\text { Step } \\
1\end{array}$} & Academic & .142 & 1.669 & .007 & 1 & .932 & 1.153 \\
\hline & TimeBalance & -.930 & 1.712 & .295 & 1 & .587 & .394 \\
\hline & htrapersonakelf & 1.890 & .996 & 3.605 & 1 & .058 & 6.622 \\
\hline & Family & -2.130 & 1.358 & 2.462 & 1 & .117 & .119 \\
\hline & RelationshipSocial & .960 & 1.043 & .848 & 1 & .357 & 2.612 \\
\hline & Academic by LnAcadenic & .001 & .415 & .000 & 1 & .998 & 1.001 \\
\hline & $\begin{array}{l}\text { LnTimeBalance by } \\
\text { TimeBalance }\end{array}$ & .256 & .467 & .301 & 1 & .583 & 1.292 \\
\hline & $\begin{array}{l}\text { intrapersonalself by } \\
\text { Intrapersonal }\end{array}$ & -.437 & .238 & 3.381 & 1 & .066 & .646 \\
\hline & Family by LnFanily & .604 & .396 & 2.334 & 1 & .127 & 1.830 \\
\hline & $\begin{array}{l}\text { InRelationship by } \\
\text { RelationshipSocial }\end{array}$ & -.291 & .300 & .943 & 1 & .331 & .747 \\
\hline & Constant & -4.594 & 7.115 & .417 & 1 & .519 & .010 \\
\hline
\end{tabular}

a. Variable(s) entered on step 1: Academic, TimeBalance, htrapersonalself, Family, RelationshipSocial, Academic * LnAcademic, LnTimeBalance * TimeBalance, Intrapersonalself * Lnhtrapersonal , Family * LnFamily , LnRelationship * Relationshipsocial

\section{Logistic Regression (Testing for Multicollinearity)}

Basically, Multicollinearity can affect the parameters of a regression model. Logistic regression is just as prone to the biasing effect of collinearity and it is essential trial to test for collinearity following a logistic regression analysis. Study obtained statistic such as the tolerance and VIF by simply 
running a linear regression analysis using the same outcome and predictors.

The result of the linear regression analysis is shown in Table 4. From above table, it can see that the tolerance value for, Academic (0.549), Time/Balance (0.497), Intrapersonal/Self (0.401), Family (0.623) and Relationship/social (0.594). (Andy, 2009) suggests that a tolerance value less than 0.1 almost certainly indicates a serious collinearity problem. It seems from these values that there is none issue of collinearity between the predictor variables.

Table 3. Multicollinearity

\begin{tabular}{|ll|r|c|}
\hline \multicolumn{4}{|c|}{ Coefficients } \\
\hline \multirow{2}{*}{ Model } & & \multicolumn{2}{c|}{ Collinearity Statistics } \\
\cline { 2 - 4 } & & Tolerance & VIF \\
\hline 1 & Academic & .549 & 1.822 \\
& TimeBalance & .497 & 2.011 \\
& ntrapersonalself & .401 & 2.495 \\
& Family & .623 & 1.606 \\
& RelationshipSocial & .594 & 1.685 \\
\hline
\end{tabular}

a. Dependent Variable: stress

\section{Discussions}

\section{Academic Stressors}

The intent of this exploratory study was to identify whether academic stressors has relationship with students successfully. This important because academic performance is the most critical concern of students, especially first year students and that problem perceived to be most intense source of stress are examination grades, financial concerns, fear of failure specific assignments and career decisions as discusses in (Benjamin and Libby, 1987). Students in this study did not scored more in academic stressors, which is mean that academic stressors does not have any relationship with their stress. Although it might seen surprising, but after through study about this stressors, we can say that it might happen because of the period of questionnaire is distributed to the respondents. Questionnaires are given during early or beginning of the semester whereby, students are not much think of the texts, exams, presentations, meeting deadlines of assignments and etc. Secondly, it also could be because of students have a very good relationship with their respective lecturers. This relationship brought students to consult and always clarify whenever they have doubts on their studies.

\section{Interpersonal Stressors}

There is a saying "No one is perfect". Likewise it is very difficult to have perfect interpersonal relationship among people. Such imperfect interpersonal skills can be factor with students stress. However stress can be overcome or reduce by high EQ (Emotional Intelligence). By adopting EQ such as discussing issues together and having the negotiation skills, expressing anger appropriately without bad attitude and fighting, students will be able to solve this communication problem, as cited in (Kaplan, 1996). In the study, findings shows that interpersonal stressors are not one of the factors contribute to students stress. So from the finding, we would say that it may be because students have high EQ to overcome interpersonal stress. Apart from that, based on our observation interpersonal stressor is not one factor of stress could be because students love to talk and share their problems with their friends. Stress can be a 
little less daunting if students have someone to talk it over with. Voicing their concerns to a friend will deflate some of that built up stress. Whether they talk about a specific stress causing event or talk about stressingout in general, they will feel better. The added benefit is that by opening up to a friend, they may help them out also. Their friends are probably feeling stressed too. Students may even be able to help each other de-stress by doing something fun together. Lastly, our study predicting that students know how to give their brain rest and recuperate. For example going out dancing, watching movies, hanging out with friends actually give them to relax and reduce down the stress level.

\section{Family stressors}

Based on above results we would say that CDP students do not have stress caused by family stressors. Family is a key factor to one's development. Family closeness is thus fundamental to the development of happy and competent children and adults. So it is can be predicted that CDP students count on their family to be able to overcome the problem that they face in studies and life. Students may be spend time with their family and share the feelings by setting aside the pressure of university, work or difficult relationships.

\section{Time/Balance}

Unlike previous studies, time/balance stressors does not contribute to students stress in CDP. Students across the country will agree that time management is a major hurdle for college students. Finding balance between coursework, studying, socializing, and work is a daunting task which is lead to students stress. However, if they are proper planner in certain part of their life, the students are able to manage their time effectively. We believe that, respondents might have their own planer to help them keep track of due dates. Apart from that, they might also have their own goal setting. With realistic goals, they will have something concentrate to work toward and the light at the end of the tunnel can be seen. Combined with time balance, setting priorities help them on schedule.

\section{Relationship/Social}

Finally, respondents are free from relationships problems which will cause them stress. In our opinion, students can get along well with others could be because they are closely connected to social network. Many people reported the internet was needed to maintain social interactions as mention in (McMillan and Morrison, 2006). Inherently this means it is important for students in interpersonal relationships to use the Internet to interact. In addition, CDP students as mentioned before, they might have high EQ. Once they have it, they are willing to listen to people carefully and have empathy and understand others. In the area of "peer support" studies about students making friends with each other have been conducted, which show that receiving support from their friends has the following benefits.

It was indicated that friendship is closely related to satisfaction in school life, as mention in (MichiyoOkada et al., 2010). Once students satisfied in their school life, the level of depression and stress can be reducing. The students in MMU Melaka campus seem that have good friendship among them, and in supportive friendships is closely related to alleviation of depression, and friendship itself affects their healthy mental health.

\section{Conclusion}

As a conclusion, this study has produced information about stress according to identified stressors such as academic, time/balance, interpersonal/self, relationship/social and family. It is suggested that these information's only are not sufficient enough to be used as a necessary components of a stress management program specific to the needs of university students. Additionally, an improvised method 
can be used in a stress management workshop especially to the highest type of stressors encountered by university students. Students should be informed of the university resources available to help them and discussed about stress. University anticipates student stress and provide workshop on coping skills, guest speaker, and activities designed to help students deal. The topic of the stressors may include time management, recognizing stress, money management, relationship and study habits. Even though the dangers of extreme stress leading to psychological damage are not seen in our campus, stress can potentially interfere with learning, academic performance and worsen student's problems. Although most university student stress is self manageable, there are situations that may be serious enough to require counseling or advice of the professionals. It is wise for parents too to take time to recognize the stresses on students face. If they then provide stress management techniques, they will do much to relieve and encourage their students. Stress in the university cannot be abolished but we should do a better job preparing our students to manage it.

\section{References}

Abouserie, R. (1994). "Sources and Levels of Stress in Relation to Locus of Control and Self Esteem in university Students," Educational Psychology, 14, pp. 323-330.

Asri Mohamad. (2002). 'Hubungan Sokongan Sosial dengan Tekanan di kalangan Remaja: Satu Kajian Remaja Bandar dan Luar Bandar Daerah Kemaman,' Terengganu, Latihan Ilmiah yang tidak diterbitkan. Universiti Putra Malaysia (UPM) Serdang.

Awino, J. O. \& Agolla, J. E. (2008). "A Quest for Sustainable Quality Assurance Measurement for Universities: Case of Study of the University of Botswana," Educ. Res. Rev. 3 (6), pp. 213-218.

Benjamin, L. \& Libby (1987). 'Understanding and Managing Stress in the Academic Worl,'
ERIC Clearinghouse on Counseling and Personnel Services Ann Arbor, MI. 60.

Brittany Gower, Christina E. Hand \& Zachariah K. Crooks. (2007). "The Relationship between Stress and Eating in College-Aged Students," Undergraduate Research Journal for the Human Sciences, 7. Electronic copy available at: http://www.kon.org/urc/v7/crooks.html

Burge, J. (2009). 'Coping Frequency, Coping Effectiveness, and Personality Factors in University Students,' Unpublished Honours thesis, University of Canberra, Australia.

Burnett, P. C. \& Fanshawe, J. P. (1997). "Measuring School-Related Stressors in Adolescents," Journal of Youth and Adolescence, 26(4), pp. 415 - 428.

Campbell, S. W. (2006). "Perceptions of Mobile Phones in College Classrooms: Ringing, Cheating, and Classroom Policies," Communication Education. 55(3), pp. 280294.

Chew-Graham, C. A., Rogers, A. \& Yassin, N. (2003). "II Wouldn't Want It on My CV or Their Records' : Medical students' experiences of help- seeking for mental health problems," Medical Education, 37, pp. $873-880$.

Ellison, K. W. (2004). Stress and the Police Officer (2nd ed.) Springfield: Charles $C$. Thomas Publishers, IL, pp. 71-86.

Fairbrother, K. \& Warn, J. (2003). "Workplace Dimensions, Stress and Job Satisfaction," J. Managerial Psychol, 18(1), pp. 8-21.

Felsten, G. \& Wilcox, K. (1992). "Influences of Stress And Situation Specific Mastery Beliefs and Satisfaction with Social Support on WellBeing and Academic Performance," Psychological Reports, 70(1), pp. 291-303.

Field, A. P. (2009). Discovering Statistics Using SPSS, 3rd ed. SAGE Publication Ltd. ISBN 978-1-84787-907-3. 
Fish, C. \& Nies, M. A. (1996)."Health Promotion Needs of Students in a College Environmen," Public health Nursing, 13, pp. $104-111$.

Greenberg, J. \& Baron, R. A. (2000). Behavior in Organizations (7th ed.), Upper Saddle River, NJ: Prentice Hall.

Jewett, M. E. (1997). 'Models of Circadian and Homeostatic Regulation of Human Performance and Alertness,' PhD thesis, Harvard University, pp. 1-276.

Kaplan, L. S. (May 24, 1996). "Helping Gifted Students with Stress Management," Retrieved October 14, 2007. Electronic copy available

at: http://www.kidsource.com/kidsource/co ntent/stress_management.html.

Lohaus, A. (1990). 'Gesundheit und Krankheit aus der Sicht von Kindern,' Göttingen: Hogrefe. As cited in Greda. K, Maurice. P.Z, Gerjo. K, Clemens. H, Huda. H. AS. (2006). School Programs Targeting Stress Management in Children and Adolescents: A Meta-Analysis. Journal of School Psychology 44, pp. 449-472.

Lumley, M. A. \& Provenzano, K. M. (2003). "Stress Management through Emotional Disclosure Improves Academic Performance among College Students with Physical Symptoms," Journal of Educational Psychology, 95, pp. 641-649.

Maureen, J. (2009). "Community College Students' Perceptions of Stress," Journal Biology of Exercise, 5(1), pp 15-28.

McMillan, S. J. \& Morrison, M. (2006). "Coming of Age in the E- Generation: A Qualitative Exploration of How the Internet Has Become an Integral Part of Young People's Lives," New Media \& Society, 8, pp. 73- 95.

McNamara, S. (2000). Stress in Young People: What's New and What Can We Do?, London: Continuum International Publishing Group.
Michiyo Okada, Takeshi Suzue \& Fumihiko Jitsunari (2010). "Association between Interpersonal Relationship among HighSchool Students and Mental Health," Environ Health Prev Med, pp.57-62.

Newman, J. (2005). 'Early Life Stress Linked to Teenaga Mental Problems,' Oregon Health \& Science University.

Ong, B. \& Cheong, K. C. (2009). "Sources of Stress among College Students - The Case of a Credit Transfer Program," College Student Journal, 43(4), pp. 1279.

Ongori, H. (2007). "A Review of the Literature on Employee Turnover," African J. Bus. Management, 1(3), pp. 49-54.

Ongori, H. \& Agolla, J. E. (2009). "An Assessment of Academic Stress among Undergraduate Students: The Case of University of Botswana," Journal of Educational Research and Review, 4 (2), pp. 063-070.

Ratanasiripong, Paul Burkey, Heid, \& Nop (2005). 'Stress and Substance Use among Asianamerican and Latino College Students,' College Student Journal, 43(4), pp.1253-1259.

Redhwan, Sami, Karim, Chan \& Zaleha, (2009). 'Stress and Coping Strategies among Managementand Science University Students: A Qualitative Study,' Journal of the International Medical, 8(2), pp. 11-15.

Rees, C. J. \& Redfern, D, (2000). "Recognising the Perceived Causes of Stress: A Training and Development Perspective," Ind. and Commer. Train. 32(4), pp. 120-127.

Richlin-Klonsky, Judith \& Ruan Hoe (2003). "Sources and Levels of Stress among UCLA Students," Journal of Student Affairs, 2, pp. 113.

Saipanis, R. (2003). "Stress among Medical Students in a Thai Medical School," Medical Teacher, 25, pp. $502-506$. 
Shaikh, B. T., Kahloon, A., Kazmi, M., Khalid, H., Nawaz, K., Khan, N. A. \& Khan, S. (2004). "Students, Stress and Coping Strategies: A Case of Pakistani Medical School," Journal of Education for Health, 17(3), pp. 346 - 353.

Smith, A. (2002). 'The Scale of Perceived Occupational Stress,' Occup. Med. (50), pp. 294-8.

Stevenson, A. \& Harper, S. (2006). "Workplace Stress and the Student Learning Experience," Qual. Assur. Educ., 14(2), pp. 167-178.

Struthers, C. W., Perry, R. P. \& Menec, V. H. (2000). "An Examination of the Relationships between Academic Stress, Coping Motivation and Performance in College," Research in Higher Education, 41(5), pp. 581 - 592.

Swick, K. J. (1987). Student Stress: A Classroom Management System, Washington: NEA Professional Library, National Education Association.

Tajularipin Sulaiman, Aminuddin Hassan, Vizata M. Sapian and Saifuddin Kumar Abdullah (2009). 'The Level of Stress among Students in Urban and Rural Secondary Schools in Malaysia,' European Journal of Social Sciences, 10(2), pp. 56-62.

Travers, C. (2010). "Unveiling a Reflective Diary Methodology for Exploring the Lived Experiences of Stress and Coping," Journal of Vocational Behavior, 79(1), pp. 204-216.

Tweed, R. G., White, K. \& Lehman, D. R. (2004). "Culture, Stress, and Coping: Internally and Externally- Targeted Control Strategies of European, Canadians, East Asian Canadians, and Japanese," J. Cross Cult. Psychol, (35), pp. 652-668.

World Health Organization (1994). 'The Health of Young People: A Challenge and a Promise,' Geneva: WHO. 